\title{
USEFULNESS OF COMPREHENSIVE INCOME STATEMENT - PRELIMINARY STUDY ON THE EXAMPLE OF COMPANIES FROM THE WIG30 INDEX
}

\section{Przemyslaw Czajor}

University of Lodz, Faculty of Management, Lodz, Poland

e-mail: przemyslaw.czajor@uni.lodz.pl

ORCID: 0000-0003-2812-2918

\section{Piotr Druszcz}

Poznan University of Economics and Business, Poznan, Poland

e-mail: piotr_druszcz@wp.pl

ORCID: 0000-0002-1165-0864

\section{Michał Hendryk}

The University of Szczecin, Szczecin, Poland

e-mail: michal.hendryk@usz.edu.pl

ORCID: 0000-0001-6473-2436

(C) 2019 Przemysław Czajor, Piotr Druszcz, Michał Hendryk

This is an open access article distributed under the Creative Commons Attribution-NonCommercial-

-NoDerivs license (http://creativecommons.org/licenses/by-nc-nd/3.0/)

DOI: 10.15611/fins.2019.4.02

JEL Classification: M41, G30

\begin{abstract}
The financial result of a company is undoubtedly the most frequently analyzed category in making economic decisions. The changing needs of financial statements users resulted in the replacement of the classic financial result with the broader concept of comprehensive income, which was regulated in the International Accounting Standard 1 Presentation of financial statements. As a result a statement of the entity's comprehensive income is created. An important element analyzed by the scientific community is the presentation of the mentioned comprehensive income and its usefulness. The purpose of the article is to determine the impact of introducing the obligation to prepare a statement of comprehensive income on the usefulness of the financial statement. The usefulness has been assessed from the perspective of the form of statement of comprehensive income and the relevance of other comprehensive income's items as compared with net income.
\end{abstract}

Keywords: comprehensive income, financial reporting. 


\section{Introduction}

The concept of comprehensive income as a measure of business performance expressing a change in the company's net assets, excluding transactions of the entity with the owners, has been the subject of numerous studies around the world for many years (Szychta, 2012). The intensification of research in this area has been primarily dictated by the regulatory changes introducing the obligation to report comprehensive income in statement of profit or loss and other comprehensive income or two separate statements of profit or loss. The issue affects companies listed on the Warsaw Stock Exchange due to the application of revised IAS 1 beginning on or after $1^{\text {st }}$ January 2009. As existing research has shown so far, academics are not entirely convinced of the usefulness of the comprehensive income. Therefore, various, often contradictory conclusions constitute the basis for further research in this area, which have to be aimed at answering the question whether the introduction of mandatory reporting of comprehensive income is justified and has a positive impact on the informational content of financial statements.

The main purpose of the paper is to determine the impact of introducing the obligation to report comprehensive income in statement of profit or loss and other comprehensive income or two separate statements of profit or loss on the usefulness of the financial statements of companies listed on the Warsaw Stock Exchange. Therefore, the following research questions were set up:

1. Do companies prefer to report other comprehensive income in statement of profit or loss and other comprehensive income or in two separate statements of profit or loss?

2. How detailed is the presentation of deferred income tax regarding other comprehensive income?

3. What is the significance level of the other comprehensive income compared to net profit/loss?

4. How the value of other comprehensive income affects the value of total comprehensive income?

5. Which items are the most significant within the category of other comprehensive income?

6. Is it possible to notice significant changes in the areas listed above during the analyzed period?

The paper is structured as follows. Section 2 discusses general principles concerning the recognition of other comprehensive income according to the revised IAS 1 . Section 3 contains a synthetic presentation of literature studies in the following area. In these parts literature review method was used as well as the analysis and interpretation of IAS 1. Section 4 was based on the analysis of consolidated financial statements for the years 2015-2018 of companies listed on the Warsaw Stock Exchange and included in WIG30 index and it answers the key research questions presented in the previous paragraph. 


\section{Principles of presenting comprehensive income according to IAS 1}

Accounting is one of the oldest fields of economics. As noted by A. Kamela-Sowińska (2014), accounting appeared earlier than mathematics, because first people gathered and protected their property, and then learned how to count it. This is also confirmed by research by D. Schmandt-Besserat (1979), according to which developed accounting systems already existed 8,000 years before Christ, so it was even earlier than people could write and count. At that time, clay tokens were used to record receivables for work. Accounting has changed dramatically since then. According to M. Kwiecien (2015), dynamic changes in the world economy, and especially in the financial market determine the evolution of accounting and its legal regulations. The evolution of accounting is the adaptation of the information and control system to changing market relations. The catalog of these adjustments includes changes in financial and non-financial reporting in recent years, and one example of this is structural changes to increase the usability of financial information.

Bek-Gaik and Walińska (2011) remind that after the amendment to IAS 1 Presentation of Financial Statements, from January 1st, 2009, the financial statements include:

- statement of financial position (balance sheet),

- statement of profit or loss and other comprehensive income (statement of comprehensive income),

- statement of changes in equity,

- statement of cash flows,

- notes, comprising a summary of significant accounting policies and other explanatory notes.

The statement of comprehensive income, which was previously a profit and loss statement, perfectly reflects the above-mentioned example of a change in the structure of the financial statement. This change is not unambiguous, as the IASB leaves freedom in many aspects.

The first of these is defined in art. 81 IAS 1, stipulating that the entity presents all items of income and expenses recognized in a given period in a single statement of comprehensive income, or two reports: a report presenting the components of profit and loss (separate profit and loss account) and in the second statement, which begins with the result from the first statement and adds components of other comprehensive income (statement of comprehensive income). It results in two ways presenting comprehensive income by enterprises:

- revenues - costs $=$ net profit/loss $+/-$ other comprehensive income $=$ total comprehensive income - here we are dealing with a statement on the total comprehensive income, or

- revenues - costs $=$ net profit/loss - in the form of a profit and loss statement and, additionally, a statement on the other comprehensive income, which consists of 
the equation net profit/loss $+/-$ other comprehensive income $=$ total comprehensive income (Sajnóg, 2018).

This total income according to IAS 1 is not only profit or loss, in the traditional, narrow sense of the term used in accounting, but a change in the amount of equity due to transactions or other events, excluding those made with the owners or shareholders (Ignatowski, 2019). It is therefore a net profit/loss reduced or increased by other comprehensive income. Introducing this change, the IASB defined a new concept - other comprehensive income. Its scope described in art. 7 of IAS 1 covers income and expense items (including reclassification adjustments) that are not recognized as profit or loss as required or permitted by other IFRSs. Other comprehensive income includes:

- changes in the surplus from the revaluation of fixed assets and intangible assets specified in the standards for these components, i.e. IAS 16 and IAS 38,

- actuarial gains and losses from benefit plans recognized in accordance with IAS 19,

- gains and losses resulting from the change of exchange rates in companies that operate abroad,

- gains and losses on the revaluation of available-for-sale financial assets presented in accordance with IAS 39,

- the effective portion of gains and losses associated with the hedging instrument as part of hedging cash flows in accordance with IAS 39.

Referring to M. Frendzel, A. Szychta (2012) rightly indicates that apart from above mentioned categories emphasized in IAS 1, IDC also covers a number of other cases, including participation in the OCI of an associate, exchange differences on the conversion of a monetary item treated as part of a net foreign investment, as well as gains or losses on the reclassification of property from property, plant and equipment to investment property.

As mentioned at the beginning of this part of the article, changes in legal regulations in the field of accounting are response to the evolving needs of users of financial statements. The implementation of the concept of total comprehensive income into the economic practice was aimed at enriching the presentation of net profit or loss with other result elements that fall within the scope of the total income of the enterprise. The purpose of adopting such a solution was to provide users of financial statements with the opportunity to perform a more complete and detailed analysis of the entity's financial position, especially its profitability (Strojek-Filus, 2015). However, considering the unambiguous way of presentation of the total income category, there appears a question if the standard fulfills its role? Studies among the users of financial statements show that there is a large correlation between where information is presented in the financial statements and its usefulness in the decision-making process (Bek-Gaik and Walińska, 2011). Therefore, it can be assumed that the recognition of information on total income in the form of one condensed or two separate reports has an impact on the usefulness of this information 
for the users of the report. In addition, the standard does not specify the level of detail in the presentation of information about the entity's total comprehensive income, which creates another problem of the usefulness of information about the amount itself constituting the category of other comprehensive income.

The doubts indicated above have contributed to many studies in this area, the synthetic review of which covers the next item of this study. What is more, the ambiguities associated with the presentation of total comprehensive income, the level of detail and the impact of individual components on the total result also prompted the authors of this publication to pose the research questions presented in the introduction and to try to answer them.

\section{Literature review on comprehensive income and its components}

The comprehensive income issue is the subject of numerous studies and publications. The intensification of research in this area has been primarily dictated by the regulatory changes, which, undoubtedly, are the main incentive for conducting multidimensional analyzes regarding the usefulness of this concept. Reviewing the actual state of this kind of research is necessary to determine the information needs of users of the statement of comprehensive income as well as the preliminary determination of the "significance" of selected economic categories presented, including in particular the category of other comprehensive income.

The initial analysis of research studies concerning comprehensive income issue allows to identify their leading direction - value-relevance studies aimed to empirical verification of usefulness of comprehensive income. The mentioned usefulness may be understood as an association between the following financial measure and stock market prices (or returns) as well as its ability to predict the future results of the entity. This type of studies concerns both aggregated comprehensive income and its particular components. Other research studies are mainly focused on the impact of net profit and comprehensive income on profitability ratios or on the form of presentation of the statement. However, the number and complexity of methods applied is definitely below.

Value-relevance research related to comprehensive income issue generally answers two key questions:

- which measure - net profit/loss or comprehensive income - provides greater information content/is more useful? (i.e., whether the disclosure of components of other comprehensive income has a positive effect on the information content/ usefulness of the financial report) and

- how, in addition to net income, one or more components of other comprehensive income are useful in increasing the explained portion of the dependent variable? (Cauwemberge van and Beelde de, 2010).

Studies categorized as a value-relevance tests were, inter alia, conducted by Cheng, Cheung, and Gopalakrishnan (1993), Dhaliwal, Subramnayam, and Trezevant 
(1999), Cahan, Courtenay, Gronewoller, and Upton (2000), Kubota, Suda, and Takehara (2007), Kanagaretnam, Mathieu and Shehata (2009) and Takahashi and Wong (2012). The results of the following studies are summarized below.

One of the oldest studies available regarding the issue of comprehensive income is the study of Cheng et al. (1993). The main objective of the study was to investigate which measure - operating result, net income or comprehensive income - is the most useful information for investors. Using a 1972-1989 sample of US companies (16,604 observations), the authors came to the conclusion that operating income and net income are much more useful information than comprehensive income in terms of the explanatory power of earnings for returns (Cheng et al., 1993).

Research conducted by Dhaliwal et al. (1999) covered 11,425 observations. The research sample included data from US market companies from the period 1994-1995. Like Cheng et al. (1993) the study does not support the claim that comprehensive income is a more useful measure of the company's performance than the net income. Moreover, authors show that the only component of comprehensive income priced by investors is unrealized gains/losses on available-for-sale securities. Other components of other comprehensive income were not value-relevant pieces of information (Dhaliwal et al., 1999).

Cahan et al. (2000) came to contradictory conclusions. On the one hand, the authors indicated that comprehensive income is a more useful measure than net income at aggregate level, but, on the other hand, they also showed that particular components of other comprehensive income are not value-relevant (Cahan et al., 2000). Due to the fact that the basis for the study was the financial information of only 48 companies (New Zealand Exchange, period 1992-1997), its results should be treated with caution.

Kubota et al. (2007) examined 4994 observations regarding companies listed on the Tokyo Stock Exchange in 2000-2005. The results of this study indicate that net income should be considered as a category more useful to investors than comprehensive income (Kubota et al., 2007).

Kanagaretnam et al. (2009) came to the opposite conclusions to previously cited studies. According to a study conducted on a sample of 203 observations from 19982003 from the Canadian market, aggregated comprehensive income is information perceived by investors as more useful than net income. They also found evidence that two components of other comprehensive income are significantly associated with price and market returns:

1. Gains and losses on remeasuring available-for-sale financial assets in accordance with IAS 39 Financial Instruments: Recognition and Measurement.

2. The effective portion of gains and losses on hedging instruments in a cash flow hedge under IAS 39 or IFRS 9 Financial Instruments.

The study presented above can be considered as one of the first showing that the introduction of mandatory reporting of comprehensive income may be useful to users of financial statements (Kanagaretnam et al., 2009). However, due to the small research sample, the results are not as much convincing. 
A study conducted by Takahashi and Wong (2012) based on a research sample of 24,949 observations obtained from the Tokyo Stock Exchange from 1998-2010 indicates that the net income increased by aggregated other comprehensive income is a measure more useful than the net income itself. At the disaggregated level, key value-relevant other comprehensive income components were as following: gains and losses on remeasuring available-for-sale financial assets, the effective portion of gains and losses on hedging instruments in a cash flow hedge as well as exchange differences from translating functional currencies into presentation currency (Takahashi and Wong, 2012).

Examining 32 entities included in the Polish electromechanical industry in 20092015, Sajnóg (2017) showed that the estimated values of the parameters of the adopted economic models indicated a higher predictive ability of comprehensive income than the net income. However, correlation analysis does not allow to consider the hypothesis as justified (Sajnóg, 2017). Therefore, the study does not prove a thesis that the usefulness of the comprehensive income is higher than the usefulness of net income.

Khan, Bradbury and, Courtnenay (2018) using financial information of 92 companies listed on the New Zealand Stock Exchange (NZSX) showed that there is a stronger association between comprehensive income and return rates than between them and net income, which, according to the concept of value-relevance research, indicates that this measure is more useful for investors than the net income. The study also provides evidence that two components of other comprehensive income - gains and losses on remeasuring available-for-sale financial assets and changes in revaluation surplus - are value-relevant (Khan et al., 2018).

Studies carried out by Sousa Fernandez and Carro Arana (2010) as well as Marchini and D'Este (2015) are examples of research on the impact of net income and comprehensive income on profitability ratios. They basically point out the fact that the application of comprehensive income instead of net income in calculation of ratios based on net income (e.g. ROE) may significantly affect their value.

According to the findings presented above, the value-relevance studies as well as impact-on-ratios studies may be considered as key trends in analyzing the usefulness of comprehensive income. The conclusions of the research are heterogeneous. Some studies indicated comprehensive income as a more useful measure than the net income (e.g. Cahan et al., 2000; Kanagaretnam et al., 2009; Takahashi and Wong 2012; Khan et al., (2018); the others reached the opposite conclusions (Cheng et al., 1993; Dhaliwal et al., 1999; Kubota et al., 2007). Therefore, putting an explicit thesis on the subject is not possible and the research on the usefulness of comprehensive income has to be continued. This paper may be considered as an introductory study preceding a thorough analysis of the usefulness of the comprehensive income in accordance with the generally accepted framework of value-relevance studies. Moreover, a large part of the study corresponds and updates the conclusions presented in Frendzel and Szychta study (2013). According to their conclusions, the usefulness 
of comprehensive income on the Polish stock market may be considered significantly limited, as most entities do not disclose the other comprehensive income at all (Frendzel and Szychta, 2013).

A synthetic summary of the conclusions of the selected studies on comprehensive income and its components is presented in Tab. 1.

Table 1. Review of selected studies on comprehensive income and its components

\begin{tabular}{|c|c|c|c|}
\hline Paper & $\begin{array}{l}\text { Sample } \\
\text { period }\end{array}$ & Sample & Results \\
\hline $\begin{array}{l}\text { Cheng et al. } \\
\text { (1993) }\end{array}$ & 1972-1989 & $\begin{array}{l}16,604 \\
\text { observations }\end{array}$ & $\begin{array}{l}\text { Operating income is definitely more useful than the } \\
\text { net income and comprehensive income }\end{array}$ \\
\hline $\begin{array}{l}\text { Dhaliwal et al. } \\
\text { (1999) }\end{array}$ & 1994-1995 & $\begin{array}{l}11,425 \\
\text { observations }\end{array}$ & $\begin{array}{l}\text { The study failed to prove the hypothesis that } \\
\text { comprehensive income is more useful than net } \\
\text { income; } \\
\text { the only component of comprehensive income priced } \\
\text { by investors is unrealized gains/losses on available- } \\
\text { for-sale securities }\end{array}$ \\
\hline $\begin{array}{l}\text { Cahan et al. } \\
(2000)\end{array}$ & 1992-1997 & $\begin{array}{l}48 \\
\text { entities }\end{array}$ & $\begin{array}{l}\text { Comprehensive income is a more useful measure } \\
\text { than net income at aggregate level; } \\
\text { particular components of other comprehensive } \\
\text { income are not value-relevant }\end{array}$ \\
\hline $\begin{array}{l}\text { Kubota et al. } \\
(2007)\end{array}$ & $2000-2005$ & $\begin{array}{l}4,994 \\
\text { observations }\end{array}$ & $\begin{array}{l}\text { Net income should be considered as a category more } \\
\text { useful to investors than comprehensive income }\end{array}$ \\
\hline $\begin{array}{l}\text { Kanagaretnam } \\
\text { et al. (2009) }\end{array}$ & 1998-2003 & 203 observations & $\begin{array}{l}\text { Comprehensive income has greater predictive power } \\
\text { than net income in forecasting future net income, } \\
\text { comprehensive income and operating cash flows }\end{array}$ \\
\hline $\begin{array}{l}\text { Sousa Fernandez } \\
\text { and Carro Arana } \\
(2010)\end{array}$ & 2004-2008 & $\begin{array}{l}35 \\
\text { entities }\end{array}$ & $\begin{array}{l}\text { The application of comprehensive income instead } \\
\text { of net income in the calculation of ROE may } \\
\text { significantly affect its value }\end{array}$ \\
\hline $\begin{array}{l}\text { Takahashi and } \\
\text { Wong (2012) }\end{array}$ & $2000-2010$ & $\begin{array}{l}24,949 \\
\text { observations }\end{array}$ & $\begin{array}{l}\text { Net income increased by aggregated other } \\
\text { comprehensive income is a measure more useful than } \\
\text { the net income itself }\end{array}$ \\
\hline $\begin{array}{l}\text { Frendzel and } \\
\text { Szychta (2013) }\end{array}$ & 2010-2011 & 140 entities & $\begin{array}{l}\text { Usefulness of comprehensive income on the Polish } \\
\text { stock market may be considered significantly } \\
\text { limited, as most entities do not disclose the other } \\
\text { comprehensive income at all }\end{array}$ \\
\hline $\begin{array}{l}\text { Marchini and } \\
\text { D’Este (2015) }\end{array}$ & $2007-2012$ & $\begin{array}{l}224 \\
\text { entities }\end{array}$ & $\begin{array}{l}\text { The application of comprehensive income instead } \\
\text { of net income in the calculation of ROE may } \\
\text { significantly affect its value }\end{array}$ \\
\hline Sajnóg (2017) & $2009-2015$ & $\begin{array}{l}22 \\
\text { entities }\end{array}$ & $\begin{array}{l}\text { The estimated values of the parameters of the adopted } \\
\text { economic models indicated a higher predictive ability } \\
\text { of comprehensive income than the net income, } \\
\text { however, correlation analysis does not allow to } \\
\text { consider the hypothesis as justified }\end{array}$ \\
\hline $\begin{array}{l}\text { Khan et al. } \\
(2018)\end{array}$ & 2003-2010 & $\begin{array}{l}92 \\
\text { entities }\end{array}$ & $\begin{array}{l}\text { Comprehensive income is a more useful measure } \\
\text { than net income }\end{array}$ \\
\hline
\end{tabular}

Source: own elaboration. 


\section{Research}

\subsection{Research design}

The objective of the research has been the analysis of statements of profit and loss and other comprehensive income of companies listed on the Warsaw Stock Exchange (WSE) and the answer to the following research questions:

1. Do companies prefer to report other comprehensive income in a combined statement of profit or loss and other comprehensive income or in a separate statement presenting other comprehensive income?

2. How detailed is the presentation of deferred income tax regarding other comprehensive income?

3. How significant is other comprehensive income (OCI) as compared with net profit/loss (net income - NI) and whether they affect the increase or decrease of total comprehensive income (TCI)?

4. What items are most significant within the category of other comprehensive income?

5. Have significant changes occurred in the areas listed above during the period under review?

The research sample comprised 30 companies included in the WIG 30 index (as for the annual revision on 15.03.2019), and the research has been performed on their consolidated financial statements for the period 2015-2018. Due to the principles of creating the WIG 30 index and restrictions on the number of companies representing the same industry sectors, it has not been possible to carry out sectoral analysis. Banks were the only sector represented by the maximum number of companies ( 7 for the WIG 30 index).

\subsection{Research findings}

The majority of companies under review (19) and all banks included in the research sample have prepared two statements - statement of profit or loss and statement of comprehensive income.

Taking into account the multi-variant approach allowed in IAS 1 for the presentation of deferred tax concerning items of OCI, four possible presentation options have been distinguished: (option 1) in detail - for each item of other comprehensive income, (option 2) general - split into items subject to reclassification to profit or loss and items not subject to reclassification to profit or loss, (option 3) general - one aggregated amount of tax effects, and (option 4) without separating deferred income tax - each item of OCI is presented net of any related tax effect. The results of the analysis are depicted in the following table. 
Table 2. Presentation of deferred income tax concerning OCI

\begin{tabular}{|l|r|r|r|r|}
\hline $\begin{array}{c}\text { Option } \\
\text { of presentation }\end{array}$ & 2015 & 2016 & 2017 & 2018 \\
\hline option 1 & 9 & 9 & 9 & 9 \\
\hline option 2 & 12 & 12 & 10 & 10 \\
\hline option 3 & 1 & 1 & 1 & 1 \\
\hline option 4 & 8 & 8 & 10 & 10 \\
\hline
\end{tabular}

Source: own study based on consolidated financial statements under review.

The most general presentation (option 3) has been chosen only by one company under survey but it is not possible to determine a dominant solution. However, it should be stressed that in 2017 there were some modifications in case of several companies.

The choice of presentation of the impact of deferred income tax affects the informative function of the statement of comprehensive income. Detailed information on deferred income tax is disclosed in the additional information, however, its lack in the statement of comprehensive income requires additional amount of work and time spent by the users of the financial statement interested in this aspect of OCI. Therefore, it can be considered that the highest informative value is represented by option 1 and option 4, which have been chosen totally by more than half of the companies under survey.

The scope of items to be recognized under other comprehensive income is subject to the regulations of individual IASs/IFRSs. Nevertheless (what is also apparent from the results of previous surveys performed by other authors), there are several items of OCI that are disclosed most often: exchange differences on translating foreign entities, the effects of measurement and reclassification of financial assets, the effects of cash flow hedges and actuarial gains/losses as the effect of employee benefits valuation. These items have been also most common in the reports of the companies under survey. For the purposes of this paper, an additional item ("other") has been identified, that includes other items ${ }^{1}$ of OCI. The table below presents how many companies have disclosed a particular item of OCI. In addition there is a consideration whether the impact of the component was positive or negative (i.e. whether it was an increase or a decrease in total income).

The results presented in the table above confirm the results of previous studies performed by other authors. On the other hand, it seems interesting that the effects of cash flow hedge are a "more frequent" item of OCI than the effects of valuation of financial assets. It is also worth noting the change in the "direction" of actuarial gains/losses. While in the years 2015-2016 this impact was more often positive

1 There have been several items of OCI included under "other" category: measurement of intangible assets and fixed assets, measurement and reclassification of investment property and share in profit of subsidiaries. 
Table 3. The scope of individual items of other comprehensive income*

\begin{tabular}{|l|r|r|r|r|}
\hline \multicolumn{1}{|c|}{ Number of OCI's items } & \multicolumn{1}{c|}{2015} & 2016 & 2017 & \multicolumn{1}{c|}{2018} \\
\hline exchange differences & $17(9)$ & $19(15)$ & $19(5)$ & $19(12)$ \\
\hline financial assets measurement & $11(3)$ & $12(4)$ & $12(10)$ & $13(8)$ \\
\hline cash flow hedge & $21(10)$ & $22(11)$ & $23(10)$ & $23(12)$ \\
\hline actuarial gains/losses & $22(13)$ & $22(16)$ & $22(4)$ & $22(5)$ \\
\hline other & $6(1)$ & $11(3)$ & $7(2)$ & $6(3)$ \\
\hline Total & $\mathbf{2 9 *}$ & $\mathbf{2 9 *}$ & $\mathbf{3 0}$ & $\mathbf{3 0}$ \\
\hline
\end{tabular}

* In parentheses there is the number of companies in which an item had a positive value

Source: own study based on consolidated financial statements under review.

(actuarial gains), in 2017-2018 there were actuarial losses in most companies (included in the study).

There is also a different amount of individual items of OCI disclosed by the companies under survey in each year.

Table 4. Number of items of other comprehensive income*

\begin{tabular}{|l|r|r|r|r|}
\hline \multicolumn{1}{|c|}{ Number of OCI's items } & 2015 & 2016 & 2017 & 2018 \\
\hline 1 & 6 & 5 & 5 & 6 \\
\hline 2 & 2 & 2 & 2 & 1 \\
\hline 3 & 8 & 8 & 10 & 7 \\
\hline 4 & 11 & 8 & 10 & 11 \\
\hline 5 & 2 & 6 & 3 & 5 \\
\hline Total & $\mathbf{2 9}^{*}$ & $\mathbf{2 9}^{*}$ & $\mathbf{3 0}$ & $\mathbf{3 0}$ \\
\hline
\end{tabular}

*One company did not disclose any OCI in the years 2015-2016

Source: own study based on consolidated financial statements under review.

Most of the companies under survey disclosed more than one item of OCI in the period 2015-2018, and on average over 20 companies in each year of the analysis disclosed at least 3 items of OCI. There has been positive or negative influence of individual items, as shown in the previous table. Therefore, the sum of OCI influences either the increase of total comprehensive income or its decrease (as compared to net income). In extreme cases, an entity with positive NI could report negative TCI. On the other hand, an entity incurring net loss (in profit or loss statement) may ultimately generate positive TCI. The significance of OCI (measured as a relation of OCI to $\mathrm{NI}^{2}$ )

${ }^{2}$ When assessing the significance of OCI, it is possible to compare it with NI or TCI. The authors of this paper have made a comparison with NI, as they believe that such information is more useful from the perspective of users of financial statements, because the level of net profit/loss seems to have a greater informative value for users of reports than the level of total comprehensive income (Ferraro and Veltri, 2012). 
for the companies included in the study was varied and ranged (in 2015-2018) from $-337 \%$ to $+268.18 \%$.

The absolute value of relation of OCI to NI has been presented in the next table. For the purposes of the study, there have been distinguished five levels of significance: up to $10 \%$, above $10 \%$ to $25 \%$, above $25 \%$ to $50 \%$, above $50 \%$ to $100 \%$ and above $100 \%$.

Table 5. The relation of OCI to NI

\begin{tabular}{|l|c|c|c|c|}
\hline \multicolumn{1}{|c|}{ Absolute relation of OCI to NI } & 2015 & 2016 & 2017 & 2018 \\
\hline$<10 \%$ & 18 & 13 & 18 & 17 \\
\hline$>10 \%-25 \%$ & 6 & 6 & 8 & 9 \\
\hline$>25 \%-50 \%$ & 3 & 6 & 3 & 2 \\
\hline$>50 \%-100 \%$ & 0 & 4 & 1 & 0 \\
\hline$>100 \%$ & 3 & 1 & 0 & 2 \\
\hline
\end{tabular}

Source: own study based on consolidated financial statements under review.

The significance of OCI was mostly negligible for companies under survey in the years 2015-2018. More than half of the companies included in the study (the exception was in 2016) disclosed OCI not higher than $10 \%$ of NI. There were only six cases in the entire 4-year period of the survey when the absolute value of OCI was higher than NI. It should be noted, however, that in four of these cases the absolute value of net income was very low (lower than $1 \%$ of equity). ${ }^{3}$

Considering that the majority of the companies under survey disclosed at least two items of OCI which influence might have been opposite, it is worth presenting the significance of individual items of OCI.

Individual items of OCI were not significant in relation to NI in most cases. Only incidentally, any item of OCI exceeded the level of NI - this occurred only for exchange differences on translating foreign entities, cash flow hedges and actuarial gains/losses. On the other hand, the impact of the components included in the group "other" (which, as indicated earlier, were disclosed only by a limited number of companies) was the least significant. It did not exceed $10 \%$ in any company and in any of the years covered by the survey.

From the perspective of the users of financial statements, it seems important to determine the significance of the items of OCI that might be reclassified to profit or loss and items that will not be reclassified to profit or loss. Items that are subject to reclassification will affect the increase or decrease of NI in future.

3 The relation of OCI to NI concerns "small numbers sensitive" and relatively low amount of OCI may appear as very significant if net income is very close to zero. This observation should be taken into account when assessing the results of surveys concerning OCI, what has been indicated also by other authors, e.g. Frendzel and Szychta (2013). 
Table 6. The relation of individual items of OCI to NI

\begin{tabular}{|c|c|c|c|c|c|c|}
\hline \multicolumn{7}{|c|}{2015} \\
\hline absolute relation of OCI to NI & none & $>0 \%-10 \%$ & $>10 \%-25 \%$ & $>25 \%-50 \%$ & $>50 \%-100 \%$ & $>100 \%$ \\
\hline exchange differences & 13 & 12 & 2 & 1 & 0 & 2 \\
\hline financial assets measurement & 19 & 9 & 1 & 1 & 0 & 0 \\
\hline cash flow hedge & 9 & 17 & 1 & 2 & 0 & 1 \\
\hline actuarial gains/losses & 8 & 21 & 0 & 0 & 0 & 1 \\
\hline other & 24 & 6 & 0 & 0 & 0 & 0 \\
\hline \multicolumn{7}{|c|}{2016} \\
\hline absolute relation of OCI to NI & none & $>0 \%-10 \%$ & $>10 \%-25 \%$ & $>25 \%-50 \%$ & $>50 \%-100 \%$ & $>100 \%$ \\
\hline exchange differences & 11 & 15 & 1 & 1 & 2 & 0 \\
\hline financial assets measurement & 18 & 6 & 2 & 4 & 0 & 0 \\
\hline cash flow hedge & 8 & 16 & 1 & 4 & 1 & 0 \\
\hline actuarial gains/losses & 8 & 18 & 2 & 0 & 1 & 1 \\
\hline other & 19 & 11 & 0 & 0 & 0 & 0 \\
\hline \multicolumn{7}{|c|}{2017} \\
\hline absolute relation of OCI to NI & none & $>0 \%-10 \%$ & $>10 \%-25 \%$ & $>25 \%-50 \%$ & $>50 \%-100 \%$ & $>100 \%$ \\
\hline exchange differences & 11 & 15 & 3 & 0 & 1 & 0 \\
\hline financial assets measurement & 18 & 7 & 5 & 0 & 0 & 0 \\
\hline cash flow hedge & 7 & 17 & 4 & 2 & 0 & 0 \\
\hline actuarial gains/losses & 8 & 20 & 1 & 1 & 0 & 0 \\
\hline other & 23 & 7 & 0 & 0 & 0 & 0 \\
\hline \multicolumn{7}{|c|}{2018} \\
\hline absolute relation of OCI to NI & none & $>0 \%-10 \%$ & $>10 \%-25 \%$ & $>25 \%-50 \%$ & $>50 \%-100 \%$ & $>100 \%$ \\
\hline exchange differences & 11 & 15 & 2 & 2 & 0 & 0 \\
\hline financial assets measurement & 17 & 12 & 1 & 0 & 0 & 0 \\
\hline cash flow hedge & 7 & 16 & 4 & 1 & 1 & 1 \\
\hline actuarial gains/losses & 8 & 18 & 2 & 1 & 0 & 0 \\
\hline other & 24 & 6 & 0 & 0 & 0 & 0 \\
\hline
\end{tabular}

Source: own study based on consolidated financial statements under review.

The significance of OCI items (defined as relation of OCI to NI exceeding 50\%) subject to reclassification occurred in 10 cases (over 4 years in relation to 30 companies, i.e. on 120 observations), while for OCI items that are not subject to reclassification such significance occurred only in 3 cases. The most of the above cases took place in 2015-2016. Taking into account the scope of the study, it is difficult to find the objective reasons for this situation. However, from the perspective of the users of the information presented in the statement of comprehensive income, the significant relation of OCI to NI for items subject to reclassification seems to be useful information. It means that in subsequent periods net income of a given 
Table 7. The relation of OCI to NI for items that are (and are not) subject to reclassification to profit or loss and items

\begin{tabular}{|c|c|c|c|c|c|c|}
\hline \multicolumn{7}{|c|}{2015} \\
\hline absolute relations of OCI to NI & none & $>0 \%-10 \%$ & $>10 \%-25 \%$ & $>25 \%-50 \%$ & $>50 \%-100 \%$ & $>100 \%$ \\
\hline OCI subject to reclassification & 2 & 17 & 4 & 4 & 0 & 3 \\
\hline OCI not subject to reclassification & 8 & 21 & 0 & 0 & 0 & 1 \\
\hline \multicolumn{7}{|c|}{2016} \\
\hline absolute relations of OCI to NI & none & $>0 \%-10 \%$ & $>10 \%-25 \%$ & $>25 \%-50 \%$ & $>50 \%-100 \%$ & $>100 \%$ \\
\hline OCI subject to reclassification & 2 & 12 & 7 & 5 & 4 & 0 \\
\hline OCI not subject to reclassification & 7 & 19 & 1 & 2 & 0 & 1 \\
\hline \multicolumn{7}{|c|}{2017} \\
\hline absolute relations of OCI to NI & none & $>0 \%-10 \%$ & $>10 \%-25 \%$ & $>25 \%-50 \%$ & $>50 \%-100 \%$ & $>100 \%$ \\
\hline OCI subject to reclassification & 1 & 17 & 7 & 4 & 1 & 0 \\
\hline OCI not subject to reclassification & 7 & 22 & 0 & 1 & 0 & 0 \\
\hline \multicolumn{7}{|c|}{2018} \\
\hline absolute relations of OCI to NI & none & $>0 \%-10 \%$ & $>10 \%-25 \%$ & $>25 \%-50 \%$ & $>50 \%-100 \%$ & $>100 \%$ \\
\hline OCI subject to reclassification & 1 & 20 & 5 & 2 & 1 & 1 \\
\hline OCI not subject to reclassification & 8 & 18 & 2 & 1 & 0 & 1 \\
\hline
\end{tabular}

Source: own study based on consolidated financial statements under review.

company may significantly increase or decrease. Therefore, such information may have a significant impact on the decision to buy, hold or sell shares of a given company.

\section{Conclusions}

The obligation to prepare a statement of comprehensive income, which has been in force for almost 10 years (regardless of its form) was intended to increase the usefulness of the financial statement. Considering the results of research carried out by the authors of this paper and the findings of previous studies, it should be pointed out that the informative value of financial statements has increased, although probably not as much as it was expected. This study confirmed the conclusions of other authors that a lack of a uniform structure of this report is noticeable (Bek-Gaik, 2013a; Bek-Gaik, 2013b). While in the opinion of the authors of this paper, the lack of an explicit obligation to prepare one or two statements concerning profit or loss and other comprehensive income does not significantly affect the assessment of the entity's financial performance, a differentiated approach to the presentation of tax effects for individual items of OCI is an element hindering the comparability of financial statements. This confirms the conclusions of Bek-Gaik and Walińska (2011) that the practice does not significantly care about the transparency and 
comprehensibility of this report for users. Thus, referring to the question formulated by Bek-Gaik (2013a) whether it would be more advisable to introduce a uniform report or to introduce more detailed notes, it can be argued that it is more justified to try to harmonize this statement, especially with regard to the presentation of tax effects. The aspect of conscious perception of the potential impact of alternative ways of presenting information, which is the area of interest in behavioral accounting (Artienwicz, 2018), has not been the subject of the study. However, the users of financial statements seem not to be eager to search for detailed information in the notes, especially when the basic element of the financial statement is subject to presentation. This argument is strengthened by the concept of homo oeconomicus, according to which human activities are focused on maximizing utility (Bąk, 2011). Therefore, since the impact of OCI on the financial situation of an enterprise is usually not material - as confirmed by the results of survey presented in this paper, as well as surveys of other authors, e.g. Frendzel and Szychta (2013), Sajnóg (2018) - potential investors are probably not willing to devote their time and work to the detailed analysis of the notes supplementing the financial statements. On the other hand, some of the items of OCI, such as actuarial gains/losses or the effects of applying cash flow hedge accounting principles, sometimes have a very significant impact on the level of total income, what has been confirmed not only in this paper, but also in previous studies (Bek-Gaik, 2013b). Hence, obligation introduced in IAS 1 to prepare the statement of comprehensive income should be considered as important as it increases the usefulness of financial statement. While the lack of its uniform structure limits the comparability of the OCI's effects among various entities, the obligation to present information at a minimum cross-section of components subject to and not subject to reclassification to profit or loss should be considered as an aspect that significantly increases the usefulness of this report, allowing for forecasting future financial results, which was also noted by Frendzel and Szychta (2013) and Sajnóg (2018).

To sum up, the introduction of an obligation (for entities reporting under IAS/ IFRS) to prepare a statement of comprehensive income should be considered important for the increase of the usefulness of financial statements. The existing alternative variants of presentation despite the progressive harmonization of solutions, which is also noted by Gierusz (2013), require from users to be aware and able to search for additional information. On the other hand, it should be emphasized that the greater importance of detailed presentation of OCI, the more frequently the effects of measurement of specific assets and liabilities are recognized in equity. Therefore, in a situation when the effects of the valuation are occasionally recognized in equity - as it is in the case of entities preparing financial statements only based on the regulations of the Polish Accounting Act - the usefulness of the statement of comprehensive income would be significantly reduced. However, for entities applying IAS/IFRS it would be useful to increase the standardization of the form of this statement. 


\section{References}

Artienwicz, N. (2018). Rachunkowość behawioralna, Warszawa: CeDeWu.

Bąk, M. (2011). Problemy behawioralne w rachunkowości przedsiębiorstwa. Finanse, Rynki Finansowe, Ubezpieczenia, (32), 47-60.

Bek-Gaik, B. (2013a). Sprawozdanie z całkowitych dochodów w świetle regulacji FASB/IASB. Zeszyty Naukowe Uniwersytetu Ekonomicznego w Krakowie, (13), 43-56.

Bek-Gaik, B. (2013b). Prezentacja innych dochodów całkowitych w sprawozdaniach finansowych wybranych spółek publicznych w Polsce w latach 2009-2011. Zeszyty Teoretyczne Rachunkowości, 70(126), 7-23.

Bek-Gaik, B., and Walińska, E. (2011). Sprawozdanie z całkowitych dochodów w praktyce wybranych spółek notowanych na GPW w Warszawie. Zeszyty Teoretyczne Rachunkowości, 62(118), 325-342.

Cahan, S. F., Courtenay, S. M., Gronewoller, P. L., and Upton D. R. (2000). Value relevance of mandated comprehensive income disclosure. Journal of Business Finance and Accounting, 27(9-10), 1273-1301.

Cauwenberge, P. P. van, and Beelde, I. de (2010). A critical note on empirical comprehensive income research. Betriebswirftschaftliche Forschung und Praxis, (62), 82-101.

Cheng, A., Cheung, J., and Gopalakrishnan V. (1993). On the usefulness of operating income, net income and comprehensive income in explaining security returns. Accounting and Business Research, (91), 195-203.

Dhaliwal, D., Subramnayam K. and Trezevant R. (1999). Is comprehensive income superior to net income as a measure of firm performance? Journal of Accounting and Economics, (26), 43-67.

Ferraro, O., and Veltri, S. (2012). A critical analysis of the empirical researches on comprehensive income value relevance. European Journal of Scientific Research, 76(4), 587-594.

Frendzel, M., and Szychta, A. (2013). Comprehensive income reporting: Empirical evidence from the Warsaw Stock Exchange. Social Sciences, 4(82), 7-16.

Gierusz, J. (2013). Postulowana forma ujawnień w sprawozdaniu z całkowitych dochodów. Prace Naukowe Uniwersytetu Ekonomicznego we Wrocławiu, (314), 31-44.

Ignatowski, R. (2019). Sprawozdanie z zysku lub straty i innych składników całkowitego dochodu (cz. I). Rachunkowość, (9), 26-38.

Kamela-Sowińska, A. (2014). Od rachunkowości do opisu gospodarczego. Zeszyty Teoretyczne Rachunkowości, 77(133), 107-115.

Kanagaretnam, K., Mathieu, R., and Shehata, M. (2009). Usefulness of comprehensive income reporting in Canada, Journal of Accounting and Public Policy, (28), 349-365.

Khan, S., Bradbury, M., and Courtnenay, S. (2018). Value relevance of comprehensive income. Australian Accounting Review, 85(28), 1-9.

Kubota, K., Suda, K., and Takehara, H. (2007). Information content of net income and other comprehensive income: Investigation of Japanese firms. (2007 Asian Academic Accounting Association Meeting, 2007 European Accounting Association Meeting, 2006 WCAE/IAAER Congress, pp. 1-36).

Kwiecień, M. (2015). Dylematy współczesnej rachunkowości, Prace Naukowe Uniwersytetu Ekonomicznego we Wrocławiu, (388), 123-136.

Marchini, P. L., and D'Este, C. (2015). Comprehensive income and financial performance ratios: Which potential effects on RoE and on firm's performance evaluation? Procedia Economics and Finance, (32), 1724-1739.

Pronobis, P., and Zülch, H. (2011). The predictive power of comprehensive income and its individual components under IFRS. Problems and Perspectives in Management, 9(4), 72-88.

Sajnóg, A. (2017). Siła predykcji zysku całkowitego w kształtowaniu przepływów pieniężnych przedsiębiorstwa. Zeszyty Naukowe Uniwersytetu Ekonomicznego w Katowicach, (322), 184-196. 
Sajnóg, A. (2018). Przydatność kategorii zysku całkowitego w zarządzaniu finansami polskich i niemieckich spółek giełdowych. Biznes międzynarodowy w gospodarce globalnej, (37), 323-335.

Schmandt-Besserat, D. (1979). Reckoning before writing. Archaeology, 32(2), 22-31.

Sousa Ferníndez, F., and Carro Arana, M. M. (2010). Comprehensive income under the crisis: Empirical evidence for Ibex-35 companies. The International Business \& Economics Research Journal, 9(1), 117-127.

Strojek-Filus, M. (2015). Pomiar i prezentacja dokonań finansowych jednostki gospodarczej w sprawozdaniu z całkowitych dochodów, Zeszyty Naukowe Uniwersytetu Ekonomicznego w Katowicach, (40), 125-141.

Szychta, A. (2012). Dochody całkowite w sprawozdaniach finansowych największych spółek notowanych na GPW w Warszawie. Acta Universitatis Lodziensis, Folia Oeconomica, (263), 65-88.

Takahashi, M., and Wong, L. (2012). The usefulness of other comprehensive income items in Japan. Discussion Papers, 1-24.

\section{UŻYTECZNOŚĆ SPRAWOZDANIA Z DOCHODÓW CALKOWITYCH A UŻYTECZNOŚĆ SPRAWOZDANIA FINANSOWEGO - BADANIE WSTĘPNE NA PRZYKŁADZIE SPÓŁEK Z INDEKSU WIG30}

Streszczenie: Wynik jednostki gospodarczej niewątpliwie jest kategorią finansową najczęściej analizowaną $\mathrm{w}$ podejmowaniu decyzji ekonomicznych. Zmieniające się potrzeby użytkowników sprawozdań finansowych spowodowały, że klasyczny wynik finansowy zastąpiono szerszym pojęciem dochodu całkowitego, które uregulowane zostało w Międzynarodowym Standardzie Rachunkowości 1 Prezentacja sprawozdań finansowych, a efektem nowelizacji tego standardu jest powstanie sprawozdania $\mathrm{z}$ całkowitych dochodów jednostki. Ważnym elementem analizowanym przez środowisko naukowe jest jednak sposób prezentacji wspomnianego wyniku całkowitego oraz jego użyteczność. Celem artykułu jest określenie wpływu wprowadzenia obowiązku sporządzania sprawozdania $\mathrm{z}$ dochodów całkowitych na użyteczność sprawozdania finansowego. Użyteczność ta została oceniona z perspektywy formy sprawozdania $\mathrm{z}$ całkowitych dochodów i istotności składników innych całkowitych dochodów w porównaniu z zyskiem netto.

Slowa kluczowe: dochód całkowity, raportowanie finansowe. 